International Journal of Child, Youth and Family Studies (2012) 1: 83-111

\title{
“I'M LUCKY” . . . TO HAVE FOUND CHILD CARE: EVOKING LUCK WHILE MANAGING CHILD CARE NEEDS IN A CHANGING ECONOMY
}

\section{Patrizia Albanese and Tanya Farr}

\begin{abstract}
This research ${ }^{1}$ looks at the impact of the rise of women's non-standard, service sector employment on gender roles, identities and relations, and compares the complex task of finding and managing formal and informal non-parental child care in rural and semi-rural communities in two policy jurisdictions (Ontario and Quebec) in the Ottawa Valley. It seeks to understand the ways in which the neo-liberal reconfiguration of local economies impact on the experiences of employed, non-urban women with young children - mitigated by provincial policy decisions - through documenting the strategies they adopt to cope with challenges when managing this family-market-state nexus. This paper specifically focuses on mothers' use of the notion of "luck" in describing how they found and managed their unique child care needs. Luck, in the psychological literature, is often treated as either an external, unstable, and uncontrollable cause, or an internal personal attribute. This paper shows that its use and invocation in response to questions about finding and managing child care has to do with gendered perceptions of control and power(lessness) over social circumstances related to geography, government policies, and changing, and at time precarious, economic/labour market circumstances.
\end{abstract}

Keywords: precarious employment, family policies, child care, mothering, luck

Corresponding author: Dr. Patrizia Albanese, Department of Sociology, Ryerson University, 350 Victoria Street, Toronto, On, M5B 2K3, palbanes@ryerson.ca

Patrizia Albanese, Ph.D. is associate professor in the Department of Sociology at Ryerson University. She teaches research methods and the sociology of childhood. She is author of Children in Canada Today (Oxford, 2009) and Child Poverty in Canada (Oxford, 2010) and coauthor (with White and Wyn) of Youth \& Society (Oxford, 2011).

Tanya Farr was an undergraduate student in the Department of Sociology at Ryerson. She is currently pursuing graduate studies. 
International Journal of Child, Youth and Family Studies (2012) 1: 83-111

In The Brave New World of Work, Ulrich Beck (2000) noted that the collapse of the welfare state, the increased individualization of economic risks, and the growing precariousness in job tenure, are part and parcel of a new "political economy of insecurity". Transformations in the organization of work contribute to insecurity, job stress, and growing levels of work-family conflict, owing to long hours and lack of control over working time (Thomas, 2009). This paper works to uncover the impact of the rise of this insecurity, job stress, and lack of control on the gender roles, identities, and relations of employed mothers managing formal and informal nonparental child care in rural and small-town (RST) communities in two policy jurisdictions, namely Ontario and Quebec. It asks: What are the strategies mothers adopt to cope with the daily challenges they face when navigating a changing RST family-market-state nexus?

Over the past three decades, the restructuring of the Canadian economy and residual welfare state, has contributed to worker displacement, increased insecurity and alienation, family earnings instability, increased reliance on multiple jobs, and growing inequalities (Bezanson \& Luxton, 2006; Bezanson, 2006a; Silver, Shields, \& Wilson, 2005; Morissette \& Ostrovsky, 2005; Luxton \& Corman, 2001; Hughes \& Lowe, 2000; Cheal, 1998; Woolley, 1998; Luxton, 1998; MacDonald, 1998; Corman, Livingstone, Luxton, \& Secombe, 1993; Luxton, Rosenberg, \& Arat-Koc, 1990; Luxton \& Maroney, 1987). Privatization, welfare state retrenchment, and global economic restructuring have been at the centre of this (Pearson, 2007; Stinson, 2006). The gendered outcomes of this restructuring at national and international levels have been profound, with mothers bearing a disproportionate share of the cost of social reproduction (Bezanson, 2006b; McDaniel, 2002; O’Connor, Orloff, \& Shaver, 1999; Bakker, 1996). Pearson (2007), for example, noted that with a growing number of women in paid work, "the increasing informalisation of employment...has left the majority of the female workforce outside regimes of welfare and social protection at the very historical moment when they have taken a vanguard role” (p. 736). Recent scholarship has begun to expose the multiple ways in which the changing nature of paid work continues to be gendered (Kessler-Harris, 2007, p. 273), yet with only some exceptions (see Leach, 2009), the impact of economic restructuring on the lives of rural women in Canada has not been the focus of much attention.

\section{Women and Work in Changing Non-urban Environments and Economies:}

Census data reveal that "rural Canada is in trouble" (Reimer, 2007, p. 3) as the population of rural areas and small towns grew by only 1\% between 2001 and 2006 . This is well below the national average (5.4\%). Trade in natural resources remains a key feature of these communities, but finding employment outside the primary sector has become essential for non-urban residents (Leach, 2009; Reimer, 2007; Nurse, 2007; Alasia, \& Magnusson, 2005; Leach \& Winson, 1995). Palmer (1994), for example, wrote about the capitalist recolonization of the "backcountry" made possible through changing communication technologies.

Authors like Ibbitson (2005) have condemned small-town Canada for being a colonialist cultural relic: conservative, static, and monocultural. On the other hand, while limited (Cummins, 2005) some research on gender roles, identities, and relationships in contemporary non-urban economies has shown that rural restructuring and change is a growing reality; and that this change has had a profound impact on rural women's paid and unpaid labour (Leach, 2009; Miewald \& McCann, 2004; Sachs, 1996; Fitchen, 1991). 
International Journal of Child, Youth and Family Studies (2012) 1: 83-111

Rural economies have been negatively affected by global economic shifts. At the local level, these shifts have been characterized, first, by moves away from farming towards manufacturing, and later, away from manufacturing towards service sector employment (Leach, 2009; Fitchen 1991). Dependency of rural areas on the state for some of the better paid service jobs (education, health services, local bureaucracy and related state services) has also tended to make rural areas vulnerable to state retrenchment and downsizing (Leach, 2009). What remain then, are lower-paid, service sector jobs (for example, see Fitchen, 1991, on rural upstate New York). This has had implications and repercussions on gender roles and relations.

Whatmore (1994) showed that changes in rural production, reproduction, and consumption have reshaped gender relations, and that women's caring labour at home directly influences their capacity to take on paid work outside the home. Heather, Skillen, Young, and Vladicka (2005) focusing on the social reproduction of patriarchal subjectivities in rural communities mapped women's triple responsibility for the survival of farm, family, and community, accentuated by agricultural and health care restructuring in Alberta. Similarly, American research by Miewald and McCann (2004) documented the impact of the declining male-dominated mining industry in the Appalachian coalfields, and the increase in femaledominated service jobs, which produced a series of struggles between men and women over appropriate gender roles relating to waged work and household work, in turn, negatively influencing social relations. Leach's (2009) research in Ontario’s North Wellington County showed that despite first holding and then losing similar jobs in manufacturing, men and women had different experiences and outcomes following the rural economic restructuring.

Some feminist researchers have argued that women's invisibility actually increased as their workloads changed (Whitzman, 2006; Heather et al., 2005; Johnston, 1998) ${ }^{2}$. At the same time, rural restructuring has forced many women to become more creative in their strategies for meeting their own and their families' physical, emotional, and economic needs (McKinley Wright, 1995).

Research is making it increasingly clear that rural restructuring has resulted in limited employment opportunities for women, further away from home, with few options when it comes to child care (Albanese, 2009; McKinley Wright, 1995; Fitchen, 1991). Leach and Winson (1995) explained that following job losses in rural manufacturing in southern Ontario, men were more likely than women to find skilled work, typically requiring long commutes. In contrast, due to family responsibilities, women were limited to seeking work in limited, micro labour markets closer to home (Leach \& Winson, 1995). This was both similar to and different from the experiences of women and families in the Upper Ottawa Valley, in Ontario and Quebec.

The Upper Ottawa/Outaouais was hit by cuts and job losses in the male-dominated forestry and logging industries even before the recent economic crisis hit other parts of Canada (Albanese, 2009; Human Resources and Skills Development Canada, 2005; Statistics Canada, 2002, 2005; Dufour, 2002). The recent economic crisis simply made matters worse, where, for example, by December 2009, monthly lumber production in sawmills decreased $14.3 \%$ compared to the same month the previous year. Production declined by $9.7 \%$ in one month alone, between November and December 2009 (Statistics Canada, 2010a). While this may be good 
International Journal of Child, Youth and Family Studies (2012) 1: 83-111

news for environmentalists, it spells the loss of some of the higher paying jobs across all industries in Canada. For example, in 2008, average weekly earnings of those working in the forestry and logging industry were $\$ 935.84$ (or $\$ 21.87$ per hour), well above average weekly earnings of those in educational services (\$862.64) and health care and social assistance (\$743.94), both of which, not surprisingly, are female-dominated industries (Statistics Canada, 2009a and 2009b) ${ }^{3}$. Job losses in the forestry and logging industry were slightly offset by gains in some service sector jobs, where average weekly earnings are low: By comparison, average weekly earnings in retail trade were $\$ 475.17$ or $\$ 13.09$ per hour (Statistics Canada, 2009a, 2009b). Customer service call centres, and other non-unionized, low-wage paying employers have emerged to set up shop near the border in Ontario, to tap into a relatively cheap, often bilingual, feminized labour force (see Akeyeampong, 2005).

\section{Rising Need for Non-parental Child Care with the Rise of Women's Service and Non- Standard Employment:}

While fertility rates have been declining across Canada, they are still higher in rural areas compared to urban centres (Malenfant, Milan, Charron, \& Bélange, 2007) and the proportion of women with young children in the labour force has been increasing steadily. By 2005, 81\% of women ages 25 to 54 were in the labour force (Marshall, 2006; Luffman, 2006), as were 71.9\% of mothers with young children (Roy, 2006). Their average time spent on paid and unpaid work also increased (Marshall, 2006). This coincides with the rise of neo-liberal governance, and the undervaluing and reprivatization of social reproduction (Albanese, 2007; Bezanson, 2006a; Stinson, 2006; Gill \& Bakker, 2003; Perrons, 2000).

With cuts to public expenditure and privatization, "good jobs" for women are being replaced with insecure, low-waged employment (Stinson, 2006; Statistics Canada, 1998). In the Ottawa Valley, this has coincided with the loss of well-paid, male-dominated jobs forcing a growing proportion of families to depend on the wages of women for subsistence. This has also resulted in women being forced to enter or re-enter the labour force soon(er) after the birth of a child, which inevitably has required them to find some form of non-parental child care.

A growing proportion of Canadians are working rotating or irregular shifts (Vanier Institute of the Family, 2010; Albanese 2009; Williams, 2008). The 2005 General Social Survey revealed that by that year, some $28 \%$ of the 14.6 million employed Canadians (a total of 4.1 million workers) worked shifts - something other than 9 to 5 (Williams, 2008). Men made up $63 \%$ of full-time shift workers, while women made up 69\% of part-time shift workers (Vanier Institute of the Family, 2010). While some claim to be "choosing" shift work to help balance work and family obligations, Canadian research has shown that shift workers report lower levels of satisfaction with their "work-life balance" compared to those working 9 to 5 (Williams, 2008; see Jacobs \& Gerson, 2001 on challenges balancing paid work and family life), and many find that the hours of operation of child care centres and some home daycares do not coincide with their actual, often rotating and shifting, child care needs (Albanese, 2009). 
International Journal of Child, Youth and Family Studies (2012) 1: 83-111

\section{Child Care Policy in Canada, and in Quebec and Ontario:}

Canada, as a whole, has been classified as a "liberal welfare state" because it relies on the free market rather than generous state support to families and social programs (Esping-Andersen, 1990, 1999, 2003). Canadian family policies, for example, are for the most part, limited, targeted, and not very “family-friendly” (O’Connor et al., 1999). But due to Canada's jurisdictional complexity, one of its provinces, Quebec, is closer to a social democratic model in its policy intents and generosity (Baker, 2006; Krull, 2007; Albanese, 2011). Since the mid1990s, Quebec has been transforming its once patriarchal and later pronatalist policies (see Albanese, 2011), towards more feminist-informed programs aimed at integrating paid work and family, promoting gender equity, and reducing family poverty (Roy \& Bernier, 2007; Jenson, 2001; Paquet, n.d.). A simplified family allowance was introduced to complement the federal National Child Benefit (Roy \& Bernier, 2007). Quebec's income tax laws were reformed, removing parents' refundable tax credit for child care expenses (the federal one remains), when it introduced $\$ 5.00$ per day (increased to $\$ 7.00$ per day in 2004) child care for children using child care at least three days a week, regardless of family income and employment status (Government of Quebec, 2006; Albanese, 2006; Government of Quebec, 2003; Tougas, 2001a, 2002a, 2002b; Bégin, Ferland, Girard, \& Gougeon, 2002). It introduced full-time, full-day kindergarten for five-year-olds and for four-year-olds living in "at-risk” neighbourhoods, and expanded school daycares at a reduced fee (\$5.00 per day per child; later \$7.00) for school-aged children in need of before- and after-school care (Albanese, 2011; Japel, Tremblay, \& Côtè, 2005), such that by 2005 there were 1,613 daycare services in Quebec schools, resulting in 81\% of public elementary schools offering them (Commission on Elementary Education, 2006; Tougas, 2001b). Quebec also negotiated its withdrawal from the national EI maternity and parental leave benefits program to offer its own system with two options to parents (effective January 2006), both with more equitable eligibility criteria and more generous replacement rates than the national plan (Albanese, 2011; Ministère de l'Emploi, de la Solidarité sociale et de la Famille, 2007; Phipps, 2006).

At the same time - in the late 1990s and early 2000s - the federal, provincial, and territorial governments were making progress towards improving access to quality child care across the country (through the National Children's Agenda in 1997, the Federal/Provincial/Territorial Early Childhood Development Agreement in 2000, and the Multilateral Framework on Early Learning and Child Care, 2003; also see Government of Canada and Government of Quebec (2005). However, after 2006, the federal Conservative minority government replaced past funding commitments with their own "Universal Childcare Benefit”, which gives families \$100 monthly, before tax, for each child under age six, and professes to provide parents with "more choice in child care” (Government of Canada, 2006). As a result, in most of the country child care spaces remain expensive and in short supply such that between 2001 and 2004, close to 60\% of all spaces created in Canada were in Quebec, further resulting in 43\% of all children registered in daycare in Canada being in Quebec (Roy, 2006). Since 2006, expansion of child care has slowed, with spaces being available to less than $20 \%$ of newborn to five-year-old children, at fees ranging from $\$ 600$ to $\$ 1,200$ per month (see Beach, Friendly, Ferns, Prabhu, \& Forer, 2009; Friendly \& Prentice, 2009). 
International Journal of Child, Youth and Family Studies (2012) 1: 83-111

Ontario set off on its own path after 2006, making some changes to its early learning programs. A new comprehensive early learning plan for Ontario was set in motion following the June 15, 2009 release of what came to be known as the "Pascal Report" or the "Premier's Report on Early Learning” (Pascal, 2009). It called for, and indeed we are seeing, the establishment of full-day learning for four- and five-year-olds in Ontario, which started in some schools in September 2010. There are plans for before- and after-school programs for school-aged children, and further recommendations for the development of new or enhanced quality programs for younger children (through networks of Child and Family Centres), and an enhanced parental leave program by 2020 (for details, see Pascal 2009). None of this, however, was in the works when interviewing for this project began in late spring, 2009.

This paper looks at mothers' responses to questions about how they fulfill and manage their child care needs in parts of rural and small town Ontario and Quebec, in the midst of a whirlwind of change and insecurity.

\section{Project Approach and Methodology}

The "distribution of paid work and caring work is inequitable" (Perrons, 2000, p.105; Kessler-Harris, 2007), and increasingly so with economic globalization (Stinson, 2006, 2007; Pearson, 2004; Bakker, 1996). Feminist political economy contends that the weight of economic and state restructuring disproportionately burdens women. It calls for political mobilization that articulates how global production depends on the labour of women, stressing that the division of labour in reproductive work still puts the bulk of household responsibilities on women (Pearson, 2004; MacDonald, 1998). Using this framework, this project sought to better understand the ways in which neo-liberal reconfigurations of non-urban economies have affected the lives and gender roles of employed, non-urban women with young children, and the strategies and networks they have adopted to cope with these changes.

I [first author] conducted 55 interviews - 22 in Quebec and 33 in Ontario - with mothers of young children currently living and employed in the Ottawa Valley. This was a nonprobability purposive sample of employed mothers working in and around two economically stagnant, small urban centres near the Ontario/Quebec border, in the Ottawa Valley ${ }^{4}$. The interviews were conducted in English in the women's homes, a community centre, or neighbouring locales, in Renfrew County, Ontario, and the Outaouais, in Pontiac County, Quebec. I zigzagged the region, travelling some 5,000 kilometres, over a three-month period, in the summer of 2009 to conduct the interviews.

All the women who responded to ads placed in daycare centres, social services agencies, in local newspapers and radio, or heard through word of mouth, and volunteered to participate in the study were employed or nearing the end of their maternity leave and soon returning to paid work. All the women, on both sides of the border, were employed in the service sector, as a lab technician, a free-lance journalist, camp counsellor, in retail sales, in customer service call centres, in office management, child care, health care, and other social and public services. All but one woman in Quebec were either married or living common-law. Six of the women in Ontario were raising their children on their own (and/or with the help of extended family), while the rest had male partners. All but one interview (at the mother's request) were tape recorded, 
International Journal of Child, Youth and Family Studies (2012) 1: 83-111

and approximately one hour in length. I asked about the women's employment history and background, and the impact that they believed their paid work had on their household work, and their personal relationships ${ }^{5}$.

I asked the mothers about whether and how their roles and responsibilities at home, at work, and their overlap have changed with paid employment; about who cares for their children, where, and at what cost; about who manages their child care arrangements; and about how some of them manage child care in light of their own and/or their partners' non-standard jobs and changing work schedules and shifts.

The interviews were transcribed in the fall of 2009 and the winter of 2010, and data analysis began in earnest, when some themes and patterns were identified and compared. The interview transcripts were analyzed through open coding (Strauss \& Corbin, 1990). This involved reviewing the transcripts line by line, uncovering a wide range of concepts and patterns. We then mapped out similarities and differences across and within the two groups (i.e., mothers in Ontario and Quebec). Open coding, the next phase in the analysis, resulted in a large number of descriptive codes including the daily challenges faced by mothers, seasonal variations in their work and family responsibilities, the role of extended family and informal social networks, and the ongoing unequal and gendered expectations around domestic division of unpaid work within their households, almost regardless of their male partners' employment status. Interestingly, closer analysis, through axial coding, resulted in the emergence of a common theme across a range of open codes. An unanticipated pattern in the responses was the recurring mention of how "lucky" mothers felt when they actually found and were able to, relatively speaking, successfully manage adequate child care arrangements. Mothers in both Ontario and Quebec evoked "luck", at times referring to very similar things, and at other times in relation to quite diverse factors and sets of experiences unique to their geographic and economic circumstances.

\section{The Psychology and Sociology of Luck:}

In the psychological literature (e.g., Weiner et al., 1971), luck has been treated and perceived as an external, unstable, and uncontrollable cause, or as the property of individual people (I am lucky or unlucky). Other researchers distinguish luck from chance, where luck is treated as a personal attribute, more external than chance, and where chance is viewed as a property of the environment (Fischhoff, 1976).

Researchers who have explored the role played by superstitious thinking have suggested that these beliefs develop in individuals with a need for control, in an attempt to overcome perceived uncertainty in their surroundings (see Wiseman \& Watt, 2004; Irwin, 2000; Jahoda, 1969; Malinowski, 1948), as a coping mechanism following traumatic experiences (Irwin, 1992; Ross \& Joshi, 1992), or among those with lower life satisfaction (Wiseman \& Watt, 2004). This is not unlike how religious people may explain God's involvement in the outcome of situations. Attributions to God/gods have been used to examine achievement motivation, helping behaviour, and coping with stressful life events. Several studies in this area have identified a relationship between individuals' locus of control and attributions to God/gods (see P. Mallery, S. Mallery, \& Gorsuch, 2000; also see Campbell, 1996). 
International Journal of Child, Youth and Family Studies (2012) 1: 83-111

According to Rotter's $(1966,1982)$ social learning theory of personality, perception of control increases when events are thought to be determined primarily by the individual's own actions. It would follow then that those who attribute their success to their own actions are also more likely to perceive they are in control of aspects of their lives. Or, perhaps even more likely, those who actually have more control over situations are more likely to perceive themselves as more successful due to their own abilities, rather than to luck or other external factors. Conversely, those with little control over their social circumstances may be more likely to attribute success and positive outcomes to chance or luck. Not surprisingly, some have found that gender is also at play here.

Research shows that young athletes, for example, often show gender differences in sport attribution, with males attributing their success to controllable or stable factors such as their own ability and effort (see Li, Lee, \& Solmon, 2006), while female athletes attributed their success to uncontrollable or unstable factors like luck and social support (Robinson \& Howe, 1989; Rudisill, 1988; Vealey, 1986) ${ }^{6}$. This was not unlike some of the responses of graduate student mothers who attributed their success to luck (Lynch, 2008), or Marion Elliott Koshland's description of her choice of career in immunology, in her autobiographical piece in the Annual Review of Immunology (Koshland 1996), or of Norwegian 14- and 15-year-old female students who were more likely than male students to believe in the importance of luck over ability in their educational efforts and success (Manger \& Eikeland, 2000). Similarly, in their study of attributes contributing to success, Försterling, Preikschas, and Agthe (2007) found that female participants more often explained the success of attractive women by invoking luck rather than ability; however, when the stimulus person was male, women attributed his success to ability rather than luck, especially when he was attractive.

Rather than explain gender differences in attributions to luck using evolutionary theories, as some psychologists like Försterling et al. (2007) have done, it may be more fruitful to seek explanations for women's reference to luck to factors connected to lack of or limited control and power. For example, Fredriksen (2005) makes it clear that "luck stands in opposition to control and not to causation" (p. 535). He adds that "to say it [a thing] happens by luck is only to say that we do not fully control these mechanisms” (p. 536) ${ }^{7}$.

According to Ronald Dworkin (2000), people's fates are determined by their choices and their circumstances, which in turn are shaped by both their personal resources (qualities of the mind and body) and impersonal resources (parts of their environment that can be owned and transferred, like land, raw material, etc.). Dworkin (2000) also distinguishes between "option luck" (the deliberate choice to take risks) and "brute luck" (unforeseen risks) and argues that in a just society, the impact of brute luck should not be reflected in the distribution of resources. But of course, it inevitably always is. Within the luck literature, Kim (2010) critically assessed Dworkin's work, focusing on gender inequality generated by the gender division of labour and unequal expectations and responsibility for child care, and its impact and relationship to paid work $^{8}$. Like many feminist scholars, Kim (2010) makes the case that the gendered social structure generated by the gender division of labour is not "a case of bad brute luck" (p. 81), explaining that equality and justice are aspects not of the "natural order" but of long-standing human arrangements that are by no means gender neutral (see also Kessler-Harris, 2001; Acker, 1990; Stansell, 1987; Lerner 1986). Many feminists have shown that states create and reinforce 
International Journal of Child, Youth and Family Studies (2012) 1: 83-111

gendered legislative agendas and social policies that codify unequal social relations and norms (Kessler-Harris, 2001; O’Connor et al., 1999; Walby, 1997). This limits women’s participation in society, including their options when it comes to paid work (Kessler-Harris, 2001), but also undervalues the enormity of women's caring work, which left unaddressed as it has been, hollows “victories” in the labour market (Folbre, 2001; Cockburn 1983,1985).

In this paper we unpack and attempt to understand two interconnected findings:

1. Our unexpected finding that many women in this study invoke the notion of luck when they describe how they have found and managed their daily child care arrangements; and

2. The reality that many of these women work very hard to do this in the midst of challenging geographic and social circumstances marred by economic insecurity, and limited, expensive, and at times inadequate options when it comes to child care.

We believe these factors have a great deal to do with government policies and (in)action. We further believe that the use of the notion of luck and chance reflect the limited control and power these women have over their family responsibilities, workplace and broader economic circumstances, and provincial and federal family policies. We found both similarities and differences across the two provincial jurisdictions.

\section{Findings}

\section{A Quebec/Ontario Difference - Rural Ontario Mothers Lucky to Have Family as the Main/Primary Child Care Providers:}

In the midst of job losses in the relatively well-paid, male-dominated forestry sector in Ontario and Quebec - resulting in increased reliance on women's employment - the notion of "luck" spontaneously surfaced in a strikingly large number of interviews. A number of mothers in both Ontario and Quebec said they were "lucky" or that a family member who could be counted upon to act as "back-up" caregiver in emergency situations was a "godsend" (more on this below). Not surprisingly, though, due to limited access to affordable, regulated child care spaces in rural Ontario - creating a need to find alternative, private, unregulated care on a regular, daily basis - more mothers in Ontario relied on family members to act as their children's main or primary caregiver while the mothers worked for pay. For example, Ontario mothers invoked luck or godsend in the following comments:

- Yeah, so thank god I had family here. My sister sort of took over the caregiving role while I was able to work. I need to work. So, so that's where we're at now. Thank god she [her daughter] goes to school in September, but then it's the staggered bell and only every other day, and...she [her sister] does lots of things with her [her daughter], and it's family, so it's a lot easier. She [sister] comes here so it makes it so much easier for morning routine. (Ontario mother, 2-024) ${ }^{9}$

- She's [her mother-in-law] just up the road here. Two minutes up the road. I feel really lucky because I have that around me to start back to work like I'm one of the lucky ones. (Ontario mother, 2-032) 
International Journal of Child, Youth and Family Studies (2012) 1: 83-111

- The only thing I'm having a hard time with is I'm back at work. I'm working two days a week. I know I could work more. I know there's the work here, but I can't put her in daycare until she's a year and a half. Um, for the first time my partner's mom is watching her. I've never had that kind of help before. So she's watching her two days a week for me, which is a total godsend because it's family, you know. You can't ask for anything better than that, but she also works. (Ontario mother, 2-034)

- We got um...my husband's [parents] are both retired so they're a godsend. (Ontario mother; 2-008)

The limited access to affordable, regulated child care in rural Ontario forced some women to turn to family members for care; and they considered themselves lucky to be able to do so. This reliance on extended family, and feeling lucky to have them around, underscored a number of interesting things, particularly in the Ontario context (there was less need to call upon family on a regular basis in Quebec because of $\$ 7.00$ per day child care). First, it demonstrates on the ground, through women's lived experiences - what feminist analyses of social policy have long argued (see O’Connor et al., 1999; Eichler, 1997): that in Canadian social policy (with, to a certain extent, the exception of Quebec), children continue to be perceived and treated as personal lifestyle choices and the individual responsibility of parents and their extended families. The state, especially in Ontario compared to Quebec, provides few supports to families with young children, forcing many to rely on private arrangements for care. These rural Ontario mothers did not see themselves as entitled to state assistance as citizens, as was the case in Quebec, but instead felt "lucky" to have extended family around to help care for their children on a regular and/or daily basis because of inadequate social policies.

Having said this, most of the women interviewed, in both Ontario and Quebec, did not have extended family living nearby. Many rural nuclear families, like other modern families, live a considerable distance from other family members; and in many cases, the children's grandparents are themselves employed and unable to help out. Contrary to conservative assumptions about the role (extended and nuclear) families should play in the care of children (Teghtsoonian, 1993, 1995), relatively few women interviewed had parents living nearby, and only some of those parents/grandparents could easily take time off work, or were retired and in relatively good health. Those who could count on extended family - this was especially visible in Ontario - felt "lucky" to have geography and family circumstances on their side.

\section{A Quebec/Ontario Difference - Rural Quebec Mothers Lucky to have Family to Fill Gaps Not Covered by State-subsidized Care:}

In Quebec, all the mothers I interviewed had access to and were using \$7.00 per day, state-subsidized child care. But this did not stop the requirement to call upon friends and family to assist with routine pick-up and drop-off from home daycares or larger centres. It was not uncommon for the Quebec mothers and their partners to be doing shift work. Often, centre hours of operation did not coincide with changing shifts and variable work schedules of either one or both parents (see Jenson, 2009, for a discussion of the limitations of Quebec's programs). On those days, mothers found themselves scrambling to find someone to fill the gap, to pick up their child before the centre closed in the evening, or drop off their child at the centre before a parent 
International Journal of Child, Youth and Family Studies (2012) 1: 83-111

returned from a night shift. One Quebec mother working in health services, in two locations some 50 kilometres apart, said:

- It's a really challenging time; again we've really been lucky with both of our parents, because they basically take her [her daughter] on the days when I'm not coming up here; so like, on the Monday, uh, I'm either home or I'm working here....and Tuesdays we come here, she stays overnight at my in-laws so that Wednesday morning when I work in [a neighbouring town] I don't have to drive her up. (Quebec mother, 1-006)

Mothers in Ontario also worked shifts, as did their partners; however, because Ontario mothers were much more likely to have private arrangements with family members or sitters (and were less likely to have centre-based care), this came up much less often in the Ontario context. Mothers in Ontario who worked shifts often worked hard and paid dearly to make private and more flexible arrangements (part-time, late night, weekends, etc.) with family members and other caregivers to suit their child care needs in a changing and precarious labour market.

\section{A Quebec/Ontario Similarity - Child Care in Emergency Situations:}

Mothers in both rural Ontario and Quebec invoked luck when they spoke about how they managed child care "emergencies". Mothers in both Ontario and Quebec who had regulated centre or home-based child care struggled to find "back-up" care when their child was ill and the centres required the child to go or stay home. When describing these kinds of situations, mothers spoke of being lucky to have the arrangements that they had. For example, when one Quebec mother received a call from her child's daycare centre saying that her son was ill and needed to be picked up, she said (an Ontario counterpart echoed the sentiment):

- I was lucky and fortunate, because my mother called to tell me that she was taking the day off...He, he was sick again, and oh no, I can't take a day off. I know I've got three meetings. Like, I'm meeting with three people today and if I reschedule, I'm going to be too squeezed somewhere else within my week. So I said I can't miss today. And if you take them to daycare when they have either diarrhoea or fever, they eventually call you back and you have to go get him. So, I just called my mom up and I was very lucky, she's like, five minutes away. And she's like, “oh you made my day. It's okay. I'm going to go spend the day with my little coco bear” and I’m like, okay good. I was lucky. (Quebec mother, 1-002)

- I mean the odd time if my mom has been able to get the day off work when she's [her daughter] been sick, then she's taken her, instead of me having to leave work. But yeah, thank god for them [her parents]. I don’t know what I would do. (Ontario mother, 2-007)

It was interesting, and striking, that despite male job losses and supposed changes to gender roles, women often counted on other women - mothers and sisters - before they turned to their male partners for the emergency or temporary care of their children. For evidence of the 
International Journal of Child, Youth and Family Studies (2012) 1: 83-111

slow pace of change, see Fox (2009) and Walzer (1998). Interviews revealed that some fathers were contributing to their children's care by either picking up or dropping off children at daycare, but for the most part it was still mothers who made the arrangements, managed the schedules, and instructed their partners or female friends and relatives who helped fill the gap on a regular basis or in child care emergencies.

\section{A Quebec/Ontario Similarity - Waiting Lists:}

Luck was often also invoked by mothers, in both rural Ontario and Quebec, when waiting lists - a problem identified by some mothers on both sides of the border - were the topic of discussion. In some of these instances, the situation was especially dire but mothers still considered themselves lucky. For example, in one case, the woman's daughter's daycare centre, located in the Ontario town where she lived [Town A], informed her that it was closing. She was given a three-month notice to find alternative care, and somehow managed to find a daycare centre not far from her workplace that would take her daughter, though this was in a town many kilometres from her home [Town B]. While this seemed ideal, it still proved to be a challenge because on the weekdays when she did not work, she was still obliged to drive her daughter to the new daycare in order to maintain her space. She nonetheless said:

- We lucked into... I don't know if it's because we're not subsidized that we were able to get a spot, I don't know, I don’t know. But I think probably we were just lucky... there was a handful of us that needed to find care and it just happened that I work in [Town B] so it was okay for us to be able to do that. And maybe some of the other people that were in [Town A], you know, don't have a job in [Town B] to bring their child to daycare. So it was just luck; luck of the draw, I think. (Ontario mother, 2-008)

In another case, a Quebec mother put her name on a waiting list when she found out that she was pregnant for the first time. Sadly, this woman spoke of being lucky to get a spot in a daycare centre in a town located in the opposite direction from her workplace, after she had miscarried twice. She told me:

- It's tough to get into daycare, so wherever you get a spot you go. [Interviewer: Did you put your name on a waiting list at different centres?] I've actually miscarried twice before her, and my name was still on the lists from the first pregnancy, and I still hadn't gotten a spot. So we were lucky to get a spot. And when it came, we ran, because I work, uh, I work about 15, I work about 20 minutes away from the daycare; so, I work 13 kilometres in one direction, and daycare is 12 kilometres in the other direction. (Quebec mother, 1-008)

\section{More Differences - Ontario Mothers More Lucky (and less supported?):}

There were many similarities in the use of the notion of luck on the two sides of the border when mothers spoke about waiting lists and having personal support they can count on. There were also differences. It was striking but not surprising to see a disproportionate number of mothers in Ontario - where child care and family policies are less generous - mention being 
International Journal of Child, Youth and Family Studies (2012) 1: 83-111

lucky in regard to a much broader range of factors and circumstances. Mothers in Ontario mentioned being lucky in relation to the location of their homes compared to their workplace (rurality and long commutes compound this problem), having understanding employers or husbands, having found "good (enough)" private child care arrangements or providers, having "manageable" schedules or routines, qualifying for a child care subsidy (due to the very high cost of care), living in rural communities, and even having a "good" or "easy" child. These women thought themselves lucky in regard to a wide range of circumstances that, for the most part, they worked very hard to manage on a daily basis.

Despite a general lack of control over workplace hours and conditions, about half of the mothers in the Ontario sample felt they were lucky to have understanding employers. There were cases where women (and not their husbands) lost hours or days of work, and their day's pay, due to their child's health and day care centres' justifiable policies around illness - part of the individualization of economic risk - but still considered themselves lucky to have understanding employers or workplaces. For example, one single mother said the following:

- Her [daughter's] dad's in Ottawa, so it's not like he's here to help. I think the biggest challenge is when she's sick, or hurts herself. They're very, very strict at that daycare, like any kind of temperature, or fever, they have to be picked up right away; so you know, I do miss a lot of work, for her being sick and stuff like that. So, I would say that's a huge challenge, 'cause then I don't get paid... [and that's] at least once a month, 'cause I mean kids at that age...At least once a month. I mean, when she first started, like she was sick all the time, like, all the time...I'm really lucky. If I had a normal job where I had to be there to answer the phones, or greet customers, I don’t know how I would do it. (Ontario mother, 2007)

Another said:

- I talked with my executive director and was able to flex my time. I was very fortunate. Yeah, so I only had to sort of, um, like I worked over my lunch hours, and I came in a little bit earlier, and you know, kind of worked it out that way. But it wouldn't have worked out for long that way because I have meetings, I have other things, you know. (Ontario mother, 2-002)

Some mothers in Ontario sacrificed their pay and/or careers, took odd shifts, worked fewer hours, worked through their lunch hour, or worked in low-paid jobs, in order to be able to manage their children's needs and balance the inevitable work-family conflict that results from lack of social supports, individualization of risk, and a residual liberal welfare state. All of this was obvious in the following examples:

- I've been very lucky that was part of my employment arrangement that they paid me a very low salary and I got to take advantage of their summer camp. (Ontario mother, 2-021)

- For the company that I worked for in the city, a lot of times we worked late. I'd work until you know, 6:00 o’clock at night, sometimes 6:30 p.m., go in on 
International Journal of Child, Youth and Family Studies (2012) 1: 83-111

Saturdays or Sundays or whatever, and after I had kids, I worked like 8:15 a.m. till 4:15 p.m. and that was it. But, I'm lucky because the company that I worked for in the city was flexible with my time. I didn't have to start right at 8:00 a.m....if I wanted to I could come in at 8:30 a.m. It didn't really matter, as long as I put in my time after that. (Ontario mother, 2-023)

- It's very exhausting, and I was off on sick leave. The last thing I needed was to find another daycare. And so I've gone back to work full-time, but I'm debating going to $90 \%$ hours...it's an option for me at work. That's why I'm very lucky, that they will do an altered work schedule because there's enough people now. But my benefits are a big thing to me, and I can't go less than $80 \%$ because I won't have my long-term disability, which is a big thing for me as well, especially now. (Ontario mother, 2-023)

- Like, we've bounced back and forth between five different people [caregivers] and we've been doing this all summer. So I was fortunate to apply for a morning rotation which I got and it will start in a couple weeks. So I'm very soon going to be moving to 7:00 a.m. till 11:00 a.m. shifts and, um, so my husband...but now the school hours have changed. (Ontario mother, 2-028)

- I could have had my name on the list as a casual [worker] or something, so that would have been beneficial for me. I don't know, I think the whole just trying to get into the daycare system and trying to figure it all out now [is difficult]...I have a month to figure out if I qualify for subsidy, and if I can get the right days that can coordinate with my boss... luckily she's been absolutely fabulous, and we're all moms here so it works out that, you know, one mom takes her kids on Thursdays [referring to a unique part-time, rotating child care arrangement] because it's over there near her house, you know, so that works out well that way. (Ontario mother, 2-034)

- Well, I was lucky. I was subsidized for most of the time 'cause my pay just wasn’t, yeah, so I was lucky that way, I didn’t pay anything. (Ontario mother, 2024)

These women spoke of luck but were resigned to accepting low wages, changing shifts, casual employment, and cuts to or extension of their (paid) work hours. This appeared to be the result of the precariousness of their household finances and job tenure, and tenacious gendered expectations about carework being women's work, regardless of their partners' employment status (men still for the most part only "helped out”). Most spoke openly about lack of opportunities, lack of flexibility and choice, and having to take whatever was available, close enough to home, to make ends meet. One mother said:

- I was working 5:00 till 9:00 in the evening and so that was very difficult you know, because I was never home and I've been doing this rotation for the past year so I'm never home at meal times, at supper time, or to... [Interviewer interrupts: Is that five days a week?] ...no, a lot of times I work sevem days a week because they're four hour shifts. So in order to build your hours and get a decent paycheck you're almost there every day...that was difficult, very difficult. (Ontario mother, 2-028) 
International Journal of Child, Youth and Family Studies (2012) 1: 83-111

Another said:

- I looked for other jobs and a lot of the places were like, oh it depends on the day, if we see that it's not busy, we'll send you home; so things like that...”. (Ontario mother, 2-027)

For many of these women, jobs were scarce, options were limited, conditions were less than ideal, and salaries were low. Nonetheless, many mentioned how lucky they were to have what they did. Some of the mothers in Ontario also considered themselves lucky when, through private arrangements (usually in unregulated care situations, also part of precarious, low-waged feminized employment), they found "understanding" caregivers, or caregivers who, while not offering healthy lunches, provided their children with a great deal of affection, or while not providing a stimulating environment, offered a safe and/or flexible child care arrangement, etc. In other words, "lucky" meant tolerating less than ideal care situations. Moreover, while expressing how lucky they were over some aspect of their child care arrangement, a number of mothers admitted or implied they feared "rocking the boat" and losing their current private arrangement. For example, some Ontario mothers stated the following:

- I was very lucky to be able to negotiate, at one point, I took a week off and...I said [to the private child care provider] we have never taken a family vacation, I would like to arrange with you that I pull her out for a week, and I don't pay you for that week. Is that something that you're flexible with? She did make that arrangement with me last year, and I think that's on the basis of our solid relationship that we've worked on...I don't think I'm going to do it this year, simply because...she has been very good to keep her once or twice a little extra, and I, I think I may do it next year. It was recently enough that I don't want to do it again right now, uh, she has been very flexible for me lately and I'm going to need a little bit of flexibility from her going into this new position so I'd rather leave that open. (Ontario mother, 2-006)

- The kids love her because she's fun, you know, and she does play with them, they love her kids. But they fight with her kids. Like, she's a lot of fun for the kids and I'm very lucky, like she does my laundry, she makes the beds, she runs the dishwasher - for which she is well paid. I've lucked out. Like, she is worth it. But then other things need to change. (Ontario mother, 2-023)

[Authors' insertion: In this case, the caregiver did not enforce house and dietary rules set by the parents, but mother does. As a result, this mother was told by her own children that they wish the child care provider was their mother instead, because she is "fun" and lenient/permissive.]

- I pulled him from there [Authors' insertion: A terrible child care arrangement where her infant son was one of over 27 children cared for in an unstimulating, private home setting] because the nature of my work [Authors' insertion: She works in child and family service delivery]. I was like okay, I'll find something, in the meantime you'll be with me, and I think it was maybe a few weeks later I found my saviour - an older couple, never had children of their own, and all she ever did from the point she was 18 was raise other people's children in the village so, and, unbelievable, loved them. Probably not the ideal food, lots of TV as well, 
International Journal of Child, Youth and Family Studies (2012) 1: 83-111

but she loved him, and he learned how to speak, he learned how to play, he was outside all the time and, um, pumped up on a lot of sugar, but you know what I'm willing to balance, I don't care, I don't care, but the key is that they care [for him]. (Ontario mother, 2-025)

- So I do a lot of juggling to minimize the impact on work, and fortunately the caregiver that we have, she has a very close friend who also babysits children in her home...she was able to kind of wedge my child in temporary arrangement as backup, so basically, if my sitter is unavailable she calls her friend and says can you take her...I did kind of have to force that a little bit in the beginning, but now with the other caregivers also, they know I'm no problem, I always pay on time, I always show up when I'm supposed to show up, there's no issues. (Ontario mother, 2-006)

- I took that first month off and, um, I didn't have confirmation that the daycare was in place. So it wasn't until approximately the last week, and so I was getting more and more stressed. Anyways, she did get into the daycare, and it is a fabulous daycare, they just are so child and family centred, and I was really fortunate because I had subsidy at first. So I had full subsidy, however then [due to government policy changes] I went from having full subsidy to going to a $400 \%$ increase... I went from one month not having to pay, to then having to pay \$400 plus dollars. (Ontario mother, 2-002)

As families increasingly relied on mothers' employment, it became clear that some Ontario mothers I interviewed found themselves scrambling, negotiating, tolerating, compromising, and paying relatively high fees - individually and privately managing workfamily conflict - in order to have something in place for their children. In this part of rural Ontario, often due to the great distances between paid work, child care centres, and home, licenced child care spaces were limited and very expensive when subsidies were not available. That said, each of the mothers above expressed how lucky they were to have what they did.

Many of the women interviewed in Quebec experienced major job losses in the lucrative, male-dominated forestry sector, and themselves worked long hours with rotating shifts, often in low-waged jobs. But Quebec family policies, with more state-funded social supports including low fee child care, created a bit of a buffer from the growing economic precariousness. One mother who was born and raised in Quebec, then lived and worked in Ontario for a time, and then returned to Quebec said:

- I worked there [in Ontario] for eight years and I had three kids in the span of four years and two months. So I had three children and I needed daycare because there's senior kindergarten. There [kindergarten in Ontario] it's part-time, whereas ours [in Quebec] is full-time. So I had to have daycare five days a week for three kids, and because one was, you know, young, one was a different fee [for] the youngest. So, going back to work after her, I paid every two weeks, $\$ 1,094$; and my pay every two weeks for 80 hours of work was $\$ 1,075$. So working 80 hours, I lost $\$ 20$ bucks. So then we had our name on a list here [in Quebec] for two years before we moved. When our name got on the top of the list, they phoned me to say, "are you moving yet?”, and we say, “no”, and she'd 
International Journal of Child, Youth and Family Studies (2012) 1: 83-111

go "okay" and give it to the person under our name and she just left me at the top... and then we were finally, like my husband had to get a job that allowed us to move, so once he got a job that allowed us to move, we moved...so I was able to go from full-time work to part-time work... and we have the same disposable income. I went from making a decent wage, to less, because you make less money here [in Quebec]; like, I lost \$5.00 an hour... [but] I was able to work less hours for less pay and still have the same amount of income. (Quebec mother 1-005)

This woman's experiences may lead some to wonder whether Quebec's generosity merely subsidizes gendered low wages (see Albanese, 2006), but the alternative in Ontario seems worse. Quebec's social policies have contributed to significant increases in women's labour force participation rates, particularly since the introduction of low fee child care (see Roy, 2006). They have also kept some families in, or allowed them to return to rural Quebec, as the above example shows. It also left this mother with more time to spend with her children, at a time when many mothers, due to long work hours, odd shifts, and long commutes, complained about not seeing their children.

\section{Discussion and Conclusions}

These interviews showed that increased individualization of economic risks and the growing precariousness in job tenure are part and parcel of a new "political economy of insecurity” (Beck, 2000) in the Ottawa Valley. Worker displacement, increased job insecurity, family earnings instability, and increased reliance on multiple jobs, as described by many other Canadian researchers including Silver et al. (2005), Morissette and Ostrovsky (2005), Luxton and Corman (2001), and Hughes and Lowe (2000), were a mounting reality for families on both sides of the Ottawa Valley.

The region's job losses in the male-dominated forestry industry (Statistics Canada, 2009a, 2009b, 2010a, 2010b) have had a significant impact on families' financial stability, placing increased importance on women's paid work and income. Families on each side of the Quebec/Ontario border found themselves struggling to manage child care arrangements that were often unsatisfactory. Despite this, mothers spoke of feeling fortunate or lucky to have what they did.

In Quebec, most references to being lucky or fortunate were connected to having (mostly female) friends and relatives available to assist with accessing the current state-subsidized, low fee child care system (Government of Quebec, 2003, 2006), that offers service of variable quality, during "regular business hours" (typically 8:00 a.m. to 5:00 p.m.) to parents who often worked variable shifts (Vanier Institute of the Family, 2010; Williams, 2008). Among the interviews with mothers living in Ontario, there were more references to luck related to actually finding, paying for, maintaining, and managing their child care needs - not surprising given the considerably less generous family policies found there.

A disproportionate number of the Ontario mothers I interviewed considered themselves "lucky" for a wider range of, at times, less than ideal situations they found themselves in. Most of these mothers were actually "unlucky" to find themselves living and working in a province 
with relatively few policies, programs, and services in place to help them balance paid work and family responsibilities. We found that many of the things women felt fortunate about were outside of their control (Fredriksen, 2005). Rather, these were in the hands of policy-makers, or were part and parcel of unequal household relations and roles in a changing and precarious labour market (P. Armstrong \& H. Armstrong, 2010; Fox, 2009; Luxton, 2009; Kim, 2010). Like Li et al. (2006), Robinson and Howe (1989), Rudisill (1988), Vealey (1986), Lynch (2008), Koshland (1996), Manger and Eikeland (2000), and Försterling et al. (2007), we found that most of these women worked very hard and creatively to make child care "work" so they could contribute to household finances. Nonetheless, they attributed their efforts and successes to luck rather than ability. Most of these women, in their own way, worked around and through the obstacles placed in front of them to find and maintain child care for their children.

Due to limited social supports to families and the high cost of care, many women in Ontario that I spoke to sacrificed their own careers in order to do this - working part-time, losing part of their pay, taking low-waged jobs or pay cuts, working through their lunch hour, accepting undesirable shifts, and/or allowing their husband's work to come first. More often than not, these women had higher levels of education than their male partners, and some had previously (but no longer) worked in well paid and stable jobs. Yet still, some considered themselves "lucky" to have anything at all when it came to child care.

In the face of long-standing policies and practices that continue to exclude and exploit women in paid work and at home (Kessler-Harris, 2007; O’Connor et al., 1999), one should not be surprised to find that when women do "manage" against great odds, some may be left feeling lucky indeed. But clearly more needs to be done to disrupt and destabilize social policies that reinforce traditional patriarchal power and roles.

In sum, we found that mothers' invocation of "luck" in responses to questions about finding and managing child care was often part of gendered perceptions and realities related to control and powerlessness over social circumstances associated with geography, government policies, and changing or at times precarious economic/labour market circumstances. The child care "situation" and child care policies affecting mothers living in this part of rural Quebec are still less than ideal, particularly when child care hours of operation do not coincide with shifting work schedules. Nonetheless, the interviewed women in Quebec were better off than those in Ontario. Employed mothers living in Ontario can now hope, given recent Ontario government commitments to early learning (Pascal, 2009), that some of their current challenges with finding, financing, and managing their child care needs will be better met. 
International Journal of Child, Youth and Family Studies (2012) 1: 83-111

\section{References}

Acker, J. (1990). Hierarchies, jobs, bodies: A theory of gendered organizations. Gender \& Society, 4(2), 139-158.

Alasia, A., \& Magnusson, E. (2005). Occupational skill level: The divide between rural and urban Canada. Rural and Small Town Canada Analysis Bulletin, 6(2) (Statistics Canada Catalogue No. 21-066-XIE). Ottawa: Statistics Canada.

Albanese, P. (2006). Small town, big benefits: The ripple effect of \$7/day child care. Canadian Review of Sociology and Anthropology, 43(2), 125-140.

Albanese, P. (2007). (Under)valuing care work: The case of child care workers in small-town Quebec. International Journal of Early Years Education, 15(2), 125-139.

Albanese, P. (2009). \$7/Day, \$7/hour and 7 days a week: Juggling commutes, low-waged shift work and child care in a changing ("new") economy. In J. Klaehn \& J. Chen (Eds.), Women across borders (pp. 26-40). Toronto: Black Rose Books.

Albanese, P. (2011). Addressing the interlocking complexity of paid work and care: Lessons from changing family policy in Quebec. In C. Krull \& J. Sempruch (Eds.), A life in balance? Reopening the family-work debate (pp. 130-143). Vancouver: UBC Press.

Akyeampong, E. B. (2005). Business support services. Perspectives On Labour \& Income, 6(5), 5-9. Ottawa: Statistics Canada.

Anderson, E. (1999). What is the point of equality. Ethics, 109(2), 287-337.

Armstrong, P., \& Armstong, H. (2010). The double ghetto (3rd updated edition). Toronto: Oxford University Press.

Baker, M. (2006). Restructuring family policies: Convergences and divergences. Toronto: University of Toronto Press.

Bakker, I. (Ed.). (1996). Rethinking restructuring: Gender and change in Canada. Toronto: University of Toronto Press.

Baynes, K. (2008). Democratic equality and respect. Theoria, 55(117), 1-25.

Beach, J., Friendly, M., Ferns, C., Prabhu, N., \& Forer, B. (2009). Early childhood education and care in Canada 2008. Toronto: Childcare Resource and Research Unit. 
International Journal of Child, Youth and Family Studies (2012) 1: 83-111

Beck, U. (2000). The brave new world of work (P. Camiller, Trans.). Cambridge, UK: Polity Press.

Bégin, L., Ferland, L., Girard, G., \& Gougeon, C. (2002). School daycare services (Gouvernement du Québec, Cat. No. 2002-02-00121). Québec: Gouvernement du Québec.

Bezanson, K. (2006a). Gender, the state \& social reproduction: Household insecurities in neoliberal times. Toronto: University of Toronto Press.

Bezanson, K. (2006b). Gender and the limits of social capital. Canadian Review of Sociology and Anthropology, 43(4), 427-443.

Bezanson, K., \& Luxton, M. (Eds). (2006). Social reproduction: Feminist political economy challenges neoliberalism. Montreal: McGill-Queen’s University Press.

Campbell, C. (1996). Half-belief and the paradox of ritual instrumental activism: A theory of modern superstition. British Journal of Sociology, 47(1), 151-166.

Cheal, D. (1998). Poverty and relative income: Family transactions and social policy. In D. Cheal, F. Woolley, \& M. Luxton (Eds.), How families cope and why policymakers need to know (pp. 1-20). Ottawa: Canadian Policy Research Networks \& Renouf Publishing Co.

Cockburn, C. (1983). Brothers: Male dominance and technological change. London: Pluto Press.

Cockburn, C. (1985). Machinery of dominance: Women, men, and technical know-how. London: Pluto Press.

Commission on Elementary Education. (2006). School daycare services: Placing quality at the heart of priorities. Quebec: Government of Quebec.

Corman, J., Livingstone, D. W., Luxton, M., \& Secombe, W. (1993). Recasting steel labour: The Stelco story. Halifax, NS: Fernwood.

Cummins, H. (2005). Unraveling the voices and identity of farm women. Identity: An International Journal of Theory and Research, 5(3), 287-302.

Dufour, D. (2002). The lumber industry: Crucial contribution to Canada's prosperity. (Manufacturing Overview Research Papers, Catalogue No. 31F0027XIE-No. 01). Ottawa: Statistics Canada.

Dworkin, R. (2000). Sovereign virtue: The theory and practice of equality. Cambridge, MA: Harvard University Press.

Dworkin, R. (2002). Sovereign virtue revisited. Ethics, 113(1), 106-143. 
International Journal of Child, Youth and Family Studies (2012) 1: 83-111

Eichler, M. (1997). Family shifts: Families, policies and gender equality. Toronto: Oxford University Press.

Eichler, M., \& Albanese, P. (2007). What is household work? A critique of assumptions underlying empirical studies of housework and an alternative approach. Canadian Journal of Sociology, 32(2), 227-258.

Esping-Andersen, G. (1990). Three worlds of welfare capitalism. London: Polity.

Esping-Andersen, G. (1999). Social foundations of post-industrial economies. Oxford: Oxford University Press.

Esping-Andersen, G. (2003). Women in the new welfare equilibrium. The European Legacy, 8(5), 599-610.

Fischhoff, B. (1976). Attribution theory and judgement under uncertainty. In J. H. Harvey, W. J. Ickes, \& R. F. Kidd (Eds.), New directions in attribution research (Vol. 1, pp. 419-450). Hillsdale, NJ: Erlbaum.

Fitchen, J. (1991). Endangered spaces, enduring places: Change, identity and survival in rural America. Boulder, CO: Westview.

Folbre, N. (2001). The invisible heart: Economics and family values. New York: New Press, 2001.

Försterling, F., Preikschas, S., \& Agthe, M. (2007). Ability, luck, and looks: An evolutionary look at achievement ascriptions and the sexual attribution bias. Journal of Personality \& Social Psychology, 92(5), 775-788.

Fox, B. (2009). When couples become parents. Toronto: University of Toronto Press.

Fredriksen, S. (2005). Luck, risk and blame. Journal of Medicine and Philosophy, 30(5), 535553.

Friendly, M., \& Prentice, S. (2009). About Canada: Childcare. Black Point, NS: Fernwood.

Gill, S., \& Bakker, I. (2003). Power, production and social reproduction: Human insecurity in the global political economy. Basingstoke, UK: Palgrave.

Government of Canada. (2006). Universal child care plan. Retrieved November 22, 2006, from http://www.universalchildcare.ca/en/faqs_benefit.shtml

Government of Canada and Government of Quebec. (2005). Canada-Quebec agreement on early learning and child care: Funding agreement. Toronto: Childcare Resource and Research 
International Journal of Child, Youth and Family Studies (2012) 1: 83-111

Unit. Retrieved June 5, 2007, from

http://action.web.ca/home/crru/rsrcs_crru_full.shtml?x=82553.

Government of Quebec. (2003). Development and funding scenarios to ensure the permanence, accessibility and quality of childcare services: Consultations 2003. Québec: Ministère de L’Emploi, de la Solidarité sociale et de la Famille.

Government of Quebec. (2006). Family and childcare services - Childcare services. Retrieved June 4, 2007, from http://www.mfa.gouv.qc.ca/thematiques/famille/servicesgarde/type/index_en.asp,

Heather, B., Skillen, L., Young, J., \& Vladicka, T. (2005). Women's gendered identities and the restructuring of rural Alberta. Sociologia Ruralis, 45(1/2), 86-97.

Hendy, H. M., \& Boyer, B. J. (1993). Gender differences in attributions for triathlon performance. Sex Roles, 29(7/8), 527-543.

Hughes, K., \& Lowe, G. (2000). Surveying the “post-industrial” landscape: Information technologies and labour market polarization in Canada. Canadian Review of Sociology and Anthropology, 37(1), 29-53.

Human Resources and Skills Development Canada. (2005). Wood products industry. Ottawa: Government of Canada (www.hrsdc.gc.ca/en/hip/hrp/sp/industry_profiles/woods.shtml).

Ibbitson, J. (2005). The polite revolution: Perfecting the American dream. Toronto: McClelland \& Stewart.

Irwin, H. J. (1992). Origins and functions of paranormal belief: The role of childhood trauma and interpersonal control. Journal of the American Society for Psychical Research, 86, 199_ 208.

Irwin, H. J. (2000). Belief in the paranormal and a sense of control over life. European Journal of Parapsychology, 15, 68-78.

Jacobs, J., \& Gerson, K. (2001). Overworked individuals or overworked families? Work \& Occupations, 28(1), 40-63.

Jahoda, G. (1969). The psychology of superstition. Harmondsworth, UK: Penguin.

Japel, C., Tremblay, R. E., \& Côté, S. (2005). Quality counts: Assessing the quality of day services based on Quebec Longitudinal Study of Child Development. IRPP: ChoicesInvesting in Our Children, 11(5), 1-42.

Jenson, J. (2001). Family policy, child care and social solidarity: The case of Quebec. In S. Prentice (Ed.), Changing child care: Five decades of child care advocacy \& policy in Canada (pp. 39-62). Halifax, NS: Fernwood Publishing. 
International Journal of Child, Youth and Family Studies (2012) 1: 83-111

Jenson, J. (2009). Rolling out or backtracking on Quebec's child care system? Ideology matters. In M. Griffin Cohen \& J. Pulkingham (Eds.), Public policy for women: The state, income security and labour market issues (pp. 50-70). Toronto: University of Toronto Press.

Johnston, M. T. (1998). Goin’ to the country: Challenges for women’s health care in rural Canada. Canadian Medical Association Journal, 159(4), 339-341.

Kaufman, A. (2004). Choice, responsibility and equality. Political Studies, 52, 819-836.

Kessler-Harris, A. (2001). In pursuit of equity: Women, men, and the quest for economic citizenship in 20th Century America. New York: Oxford University Press.

Kessler-Harris, A. (2007). Gendering labor history. Urbana: University of Illinois Press.

Kim, H.-K. (2010). Luck and the gender social structure. Journal of Women, Politics and Policy. 31(1), 67-92.

Koshland, M. E. (1996). Sheer luck made me an immunologist. Annual Review of Immunology. 14(1), ix-Xv.

Krull, C. (2007). Families and the state: Family policy in Canada. In D. Cheal (Ed.), Canadian families today: New perspectives (pp. 254-272). Don Mills, ON: Oxford University Press.

Leach, B. (2009). Transforming rural livelihoods: Gender, work, and restructuring in three Ontario communities. In B. Fox (Ed.), Family patterns, gender relations (pp. 509-522). Toronto: Oxford University Press.

Leach, B., \& Winson, A. (1995). Bringing “globalization” down to earth: Restructuring and labour in rural communities. Canadian Review of Sociology and Anthropology, 32(3), 341-364.

Lerner, G. (1986). The creation of patriarchy. Oxford: Oxford University Press.

Li, W., Lee, A., \& Solmon, M. (2006). Gender differences in beliefs about the influence of ability and effort in sport and physical activity. Sex Roles, 54(1/2), 147-156.

Luffman, J. (2006). Core-age labour force. Perspectives on Labour and Income, 7(9), 5-11 (Statistics Canada Catalogue No. 75-001-XIE). Ottawa: Statistics Canada.

Luxton, M. (1998). Families and the labour market: Coping strategies from a sociological perspective. In D. Cheal, F. Woolley, \& M. Luxton (Eds.), How families cope and why policymakers need to know (pp. 57-74). Ottawa: Canadian Policy Research Networks \& Renouf Publishing Co. 
International Journal of Child, Youth and Family Studies (2012) 1: 83-111

Luxton, M. (2009). More than a labour of love. Toronto: Canadian Scholars Press.

Luxton, M., \& Corman, J. (2001). Getting by in hard times: Gendered labour at home and on the job. Toronto: University of Toronto Press.

Luxton, M., \& Maroney, H. J. (1987). Feminism and political economy: Women’s work, women's struggles. Toronto: Methuen.

Luxton, M., Rosenberg, H., \& Arat-Koc, S. (1990). Through the kitchen window: The politics of home and family. Toronto: Garamond Press.

Lynch, K. D. (2008). Gender roles and the American academe: A case study of graduate student mothers. Gender and Education, 20(6), 585-605.

MacDonald, M. (1998). The impact of a restructured Canadian welfare state on Atlantic Canada. Social Policy \& Administration, 32(4), 389-400.

Malenfant, E. C., Milan, A., Charron, M., \& Bélange, A. (2007). Demographic changes in Canada from 1971 to 2001 across an urban-to-rural gradient (Demographic documents, research paper 008, Catalogue No. 91F0015MIE). Ottawa: Statistics Canada.

Malinowski, B. (1948). Magic, science and religion. Garden City, NY: Doubleday.

Mallery, P., Mallery, S., \& Gorsuch, R. (2000). A preliminary taxonomy of attributions to god. International Journal for the Psychology of Religion, 10(3), 135-156.

Manger, T., \& Eikeland, O.-J. (2000). On the relationship between locus of control, level of ability and gender. Scandinavian Journal of Psychology, 41(3), 225-229.

Marshall, K. (2006). Converging gender roles. Perspectives On Labour and Income, 7(7), 6-17. Ottawa: Statistics Canada.

McDaniel, S. (2002). Women's changing relations to the state and citizenship: Caring and intergenerational relations. Canadian Review of Sociology and Anthropology, 39(2), 125149.

McKinley Wright, M. (1995). “I never did fieldwork, but I milked an awful lot of cows!” Using rural women’s experiences to reconceptualize models of work. Gender \& Society, 9(2), 216-235.

Miewald, C., \& McCann, E. (2004). Gender struggle, scale and the production of place in the Appalachian coalfields. Environment \& Planning, 36(6), 1045-1064. 
International Journal of Child, Youth and Family Studies (2012) 1: 83-111

Ministère de l'Emploi, de la Solidarité sociale et de la Famille. (2007). Quebec's parental insurance plan. Retrieved on July 9, 2007, http://www.rqap.gouv.qc.ca/a-proposregime/caracteristiques_en.asp.

Morissette, R., \& Ostrovsky, Y. (2005). The instability of family earnings and family income in Canada, 1986 to 1991 and 1996 to 2001 (11F0019MIE - No. 265, Analytical Studies Branch Research Paper Series). Ottawa: Statistics Canada.

Nurse, A. (2007). Qualified differences: Diversity and cultural dynamics of small-town Canada. In B. Reimer (Ed.), Our Diverse Cities 3: Rural Communities (pp. 59-63). Ottawa, ON: Metropolis Project.

O’Connor, J., Orloff, A. S., \& Shaver, S. (1999). States, markets, families: Gender, liberalism and social policy in Australia, Canada, Great Britain and the United States. Cambridge: Cambridge University Press.

Otsuka, M. (2002). Luck, insurance, and equality. Ethics, 113(1), 40-54.

Palmer, B. (1994). Capitalism comes to the backcountry: The Goodyear invasion of Napanee. Toronto: Between the Lines.

Paquet, N. (n.d.). Toward a policy on work-family balance (Discussion paper, abridged edition). Quebec: Ministère de l’Emploi, de la Solidarité sociale et de la Famille.

Pascal, C. (2009). With our best future in mind: Implementing early learning in Ontario (Report to the Premier by the Special Advisor on Early Learning). Toronto: Queen’s Printer for Ontario.

Pearson, R. (2004). The social is political. International Feminist Journal of Politics, 6(4), 603622.

Pearson, R. (2007). Beyond women workers: Gendering CSR. Third Work Quarterly, 28(4), 731-749.

Perrons, D. (2000). Care, paid work, and leisure: Rounding the triangle. Feminist Economics, 6(1), 105-114.

Phipps, S. (2006). Working for working parents: The evolution of maternity and parental benefits in Canada. IRPP Choices, 12(2), 1-40.

Reimer, B. (2007). Immigration in the new rural economy. In B. Reimer (Ed.), Our diverse cities 3: Rural communities (pp. 3-8). Ottawa, ON: Metropolis Project.

Robinson, D. W., \& Howe, B. L. (1989). Appraisal variable/affect relationships in youth sports: A test of Weiner's Attribution Model. Journal of Sport and Exercise Psychology, 11(4), 431-443. 
International Journal of Child, Youth and Family Studies (2012) 1: 83-111

Ross, C. A., \& Joshi, S. (1992). Paranormal experiences in the general population. Journal of Nervous and Mental Disease, 180(6), 357-361.

Rotter, J. B. (1966). Generalized expectations for internal versus external control of reinforcement. Psychological Monographs, 80, 1-28.

Rotter, J. B. (1982). The development and applications of social learning theory: Selected papers. New York: Praeger.

Roy, L., \& Bernier, J. (2007). Family policy, social trends and fertility in Quebec: Experimenting with the Nordic model? Quebec: Ministère de la Famille, des Aînés et de la Condition Féminine.

Roy, F. (2006). From she to she: Changing patterns of women in the Canadian labour force. (Canadian Economic Observer: Statistics Canada Catalogue No. 11-010, pp. 3.1-3.10). Ottawa: Statistics Canada.

Rudisill, M. E. (1988). Sex differences in various cognitive and behavioral parameters in a competitive situation. International Journal of Sport Psychology, 19(4), 296-310.

Sachs, C. (1996). Gendered fields: Rural women, agriculture and environment. Boulder, CO: Westview.

Silver, S., Shields, J., \& Wilson, S. (2005). Restructuring of full-time workers: A case of transitional dislocation or social exclusion in Canada? Lessons from the 1990s. Social Policy \& Administration, 39(7), 786-801.

Stansell, C. (1987). City of women: Sex and class in New York 1789-1860. New York: Alfred A. Knopf, Inc.

Statistics Canada. (1998). 1996 Census: Labour force activity, occupation and industry, place of work, mode of transportation to work, unpaid work. The Daily of March 17. Ottawa: Author.

Statistics Canada. (2002a). Sawmills and planing mills. The Daily of March 5. Ottawa: Author.

Statistics Canada. (2005). OECD regions at a glance. The Daily, Sept. 13, 2005. Ottawa: Author.

Statistics Canada. (2009a). Table: Earnings, average weekly, by industry (all industries). Ottawa: Author. http://www40.statcan.gc.ca/101/cst01/labr73a-eng.htm.

Statistics Canada. (2009b). Table: Earnings, average hourly for hourly paid employees, by industry (all industries). Ottawa: Author. http://www40.statcan.gc.ca/101/cst01/labr74aeng.htm. 
International Journal of Child, Youth and Family Studies (2012) 1: 83-111

Statistics Canada. (2010a). Sawmills. (Service bulletin, Catalogue No. 35-003-X), 63(12), 1-22. Ottawa: Author.

Statistics Canada. (2010b). Table: Manufacturing sales, by province and territory, 2005-2009. Ottawa: Author. http://www40.statcan.gc.ca/101/cst01/manuf28-eng.htm.

Stinson, J. (2006). Impact of privatization on women. Canadian Dimension, 40(3), 27-32.

Stinson, J. (2007). We need feminist organizing now more than ever. Canadian Dimension, 41(2), 12.

Strauss, A., \& Corbin, J. (1990). Basics of qualitative research: Grounded theory procedures and techniques. Newbury Park, CA: Sage Publications.

Teghtsoonian, K. (1993). Neo-conservative ideology and opposition to federal regulation of child care services in the United States and Canada. Canadian Journal of Political Science, 26(1), 97-121.

Teghtsoonian, K. (1995). Work and/or motherhood: Ideological construction of women's options in Canadian child care policy debates. Canadian Journal of Women \& the Law, 8(2), 411-439.

Thomas, M. (2009). Regulating flexibility: The political economy of employment standards. Montreal: McGill-Queen’s University Press.

Tougas, J. (2001a). What we can learn from the Quebec experience. In G. Cleveland \& M. Krashinsky (Eds.), Our children's future: Child care policy in Canada (pp. 92-105). Toronto: University of Toronto Press.

Tougas, J. (2001b). Child care in Quebec: Where there's a will, there's a way. Child Care Advocacy Association of Canada-Parent Voices. Retrieved June 4, 2007, http://action/web.ca/home/crru/rsrcs_crru_full.shtml?x=33518.

Tougas, J. (2002a). Reforming Quebec's early childhood care and education: The first five years (Occasional Paper 17). Toronto: Childcare Resource \& Research Unit, Centre for Urban \& Community Studies.

Tougas, J. (2002b). Quebec's family policy and strategy on early childhood development and childcare. Education Canada, 39(4), 20-22.

Vanier Institute of the Family. (2010). Families working shifts. Fascinating Families, 26, 1-2.

Vealey, R. S. (1986). Conceptualization of sport-confidence and competitive orientation: Preliminary investigation and instrument development. Journal of Sport Psychology, 8, 221-246. 
International Journal of Child, Youth and Family Studies (2012) 1: 83-111

Walby, S. (1997). Gender transformations. New York: Routledge.

Walzer, S. (1998). Thinking about the baby: Gender and transitions into parenthood. Philadelphia: Temple University Press.

Weiner, B., Frieze, I., Kukla, A., Reed, L., Rest, S., \& Rosenbaum, R. M. (1971). Perceiving the causes of success and failure. In E. E. Jones, D. E. Kanousse, H. H. Kelley, R. E. Nisbett, S. Valins, \& B. Weiner (Eds.), Attribution: Perceiving the causes of behavior (pp. 95120). New York: General Learning Press.

Whatmore, S. (1994). Theoretical achievements and challenges of European rural gender studies. In L. Van der Plas \& M. Fonte (Eds.), Rural gender studies in Europe (pp. 39-49). Assen, Netherlands: Van Gorcum.

Whitzman, C. (2006). At the intersection of invisibilities: Canadian women, homelessness and health outside the "big city”. Gender, Place and Culture, 13(4), 383-399.

Williams, C. (2008). Work-life balance of shift workers. Perspectives on Labour and Income, 9(8), 5-16 (Statistics Canada, Catalogue No. 75-001-X). Ottawa: Statistics Canada.

Wiseman, R., \& Watt, C. (2004). Measuring superstitious belief: Why lucky charms matter. Personality \& Individual Differences, 37(8), 1533-1541.

Woolley, F. (1998). Work and household transactions: An economist's view. In D. Cheal, F. Woolley, \& M. Luxton (Eds.), How families cope and why policymakers need to know (pp. 27-56). Ottawa: Canadian Policy Research Networks \& Renouf Publishing Co.

\section{Endnotes}

1 This project was made possible through funding from the Social Sciences and Humanities Research Council, Standard Research Grant (2008-2011).

2 Johnston (1998) noted that rural Canadians produce 40\% of GNP but receive only 10\% of services in health and education.

3 Between 2005 and 2009, manufacturing sales in both Ontario and Quebec saw a sharp decline. In Quebec, manufacturing sales dropped from \$139,556.4 million in 2005 to \$128,2787.3 million in 2009, while in Ontario they dropped from \$303,607.2 million to \$223,257.4 million in 2009 (Statistics Canada, 2010b).

${ }^{4}$ I was interviewed by two reporters for two different regional newspapers (one in Ontario and one in Quebec), where I described the project, had my contact information, and asked for study 
participants. I also placed a radio ad in a non-for-profit French and English community radio station in Quebec. I posted flyers at local child care centres, at and through two agencies (Centres De Petit Enfance/CPEs in Quebec), and at organizations that were frequented by both licensed and unlicensed home daycare providers. I was granted permissions to post information about the study and my contact information on a child and family services website. Through the site and its connected listserv, the study information circulated through various networks across Renfrew County. I returned mothers' calls and set up appointments for interviews throughout the region. The mothers in Quebec were bilingual, so all 22 interviews were conducted in English.

5 Eichler and Albanese (2007) use the term "household work" to include both housework and care work.

${ }^{6}$ One exception that runs counter to past studies is Hendy and Boyer's (1993) work, which found that female triathletes downplayed the importance of luck.

${ }^{7}$ For a number of reasons, this paper will not include a detailed discussion of luck egalitarianism - the view about distributive justice found among egalitarian and political philosophers, which assumes that social inequality is the result of both luck/arbitrary influences (misfortunes in genetic makeup or outcomes of accidents, for example) and the consequence of conscious options/personal choices. For a detailed discussion see Baynes (2008), Kaufman (2004), Dworkin (2002), Otsuka (2002), and Anderson (1999).

8 There is large body of feminist literature documenting and analyzing gender inequality in paid and unpaid work. For Canadian literature, see P. Armstrong and H. Armstrong (2010), Fox (2009), and Luxton (2009).

9 Interview ID numbers starting with "1-” represent mothers living in Quebec; those starting with "2-” represent mothers living in Ontario. The women's names, names of their children, and the names of towns, communities, and employers have either not been included or have been changed to maintain confidentiality. 